\title{
THE ROLE OF IRRIGATION IN DEVELOPMENT OF AGRICULTURE IN SREM DISTRICT ${ }^{1}$
}

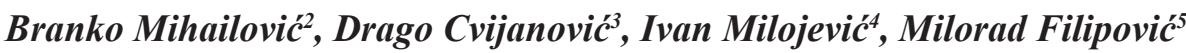

\begin{abstract}
Applying irrigation get high production results and economics of investments in irrigation systems points out that this measure in agricultural production should be given a priority. By irrigation can stabilize, i.e. increase food production and encourage the development of livestock breeding, processing and other branches of economy in the region of Vojvodina and Srem area. Accordingly, the basic goals of the research are: 1) evaluation of factors of agricultural development with the analysis of impact to the planned construction and exploitation of the irrigation system, 2) market aspects of establishing the irrigation system with water of Srem region, 3) evaluation of market efficiency of agricultural production and 4) defining approach for determination of a new sowing structure under irrigation.

Research has shown that irrigation increases the agricultural production efficiency, there makes impact to sowing structure change, and the market surpluses on the international market can be sold, by using the existing international agreements, signed by the Republic of Serbia. However, besides a great potential in the sector of agricultural production, as the result of favourable climatic conditions, natural land characteristics and available water resources, signed agreements on free trade - the potentials in agro-food sector have not been sufficiently used.
\end{abstract}

Key words: irrigation, agricultural development, competitiveness, efficiency.

JEL: $Q 1, Q 5$

1 Paper is a part of research within the project no. III 46006 - Sustainable agriculture and rural development in the function of accomplishing strategic objectives of the Republic of Serbia in the Danube region, financed by the Ministry of Education, Science and Technological Development of the Republic of Serbia, for the project period 2011-2014.

2 Branko Mihailović, Ph.D., Scientific Associate, Institute of Agricultural Economics, Volgina Street no. 15, 11060 Belgrade, Serbia, Phone: +381 1169 72 858, E-mail: brankomih@neobee.net

3 Professor Drago Cvijanović, Ph.D., Scientific Adviser, Institute of Agricultural Economics, Volgina Street no. 15, 11060 Belgrade, Serbia, Phone: +381 116972 858, E-mail: drago_c@iep.bg.ac.rs

4 Professor Ivan Milojević, Ph.D., University of Defence Belgrade, Military Academy, Pavla Jurišića Šturma Street no. 33, 11000 Belgrade, Serbia, Phone: +381 113603 247, E-mail: drimilojevic@gmail.com

5 Professor Milorad Filipović, Ph.D., University in Belgrade, Faculty of Economics, Kamenička Street no. 6, 11000 Belgrade, Serbia, Phone: +381 6413809 46, E-mail: miloradf(a,kof.bg.ac.rs

EP 2014 (61) 4 (989-1004) 


\section{Introduction}

Started changes in the field of economy, although under the influence of numerous factors which have a depreciation effect, have acquired the character of irreversible processes. Namely, reform of economic system can hardly be back to a starting position, but first of all on its hesitating tempo and instruments of macro-economic policy can be spoken, which often should establish a balance between diametrically opposed economic goals. On the other hand, standard of the population in the Republic of Serbia, measured by GDP/per capita, amounts 4,112 EUR, and the main problem of its increase in the following period can be found in inefficient institutions of systems and absence of common infrastructural reforms.

Technological obsolescence of Serbian industry is a serious obstruction in further development of industrial production and achievement of high production standards and quality of final products, which on the developed countries' market are required (ILO, 2010).

According to 154 surveyed enterprises (small, medium and big enterprises) in the whole Serbia, data point out that the average age of machines and equipment in food industry is 27.17 years. In Central Serbia the average age of machines and equipment in food industry is also around 27 years. The situation is slightly better in Vojvodina, since that the average age of machine and equipment of 22 years in food industry has been registered.

The highest gross rate of job creation in the year 2011 had the region of Vojvodina. However, in this region was at the same time realized also the largest outflow of employees, so that apparently important increase of employment has contributed to the rate of newly-created jobs of $2.2 \%$, which approximately suits to the republic average level (National Employment Service of Serbia, 2012).

According to the same source, the Belgrade region had the lowest gross rates of creation and termination of jobs, so a net rate of jobs creation was amounted $2.07 \%$ in Serbia, or some more than the average net rate of created jobs in the Republic of Serbia.

In the region of Šumadija and West Serbia was rated the highest net rate of job creation, which was amounted $2.25 \%$ in the year 2011, and this could be an important indicator of the regional economies revival. However, in the region of South and East Serbia was realized the lowest net rate of jobs creation - 1.59 (ILO, 2010).

It is important to emphasize that agriculture cannot go on employing a number of people currently employed, and to be competitive in the environment instantaneously, and especially on the EU market. Conflict of agriculture role in economic development and its social component characterizes constantly the economic structure of Serbia, and precise demarcation of development-oriented agricultural husbandries which belong in the domain of social and rural policy of a state - are necessary for defining clear directives of construction of a competitive agro-food sector in the future. 
The most important elements of the reform processes in the agrarian sector of Serbia since 2000 until today have been: market liberalization, privatization of processing industry, activation of agrarian financial market, as well as forming new institutional forms at all levels. In the following period Serbia should become a member of WTO and to apply fully the accepted rules, which mean significantly reduction of import protection, elimination of export subsidies and change of internal support structure to the domestic agricultural production.

Assumptions based on a stationary climate may no longer be tenable (Milly et al., 2008). Namely, observing climatic changes, primarily air temperature and precipitation (their amounts and disposition during the whole hydrological year and during the vegetation period), globally in the following years the intensive climatic changes will be expected. Those changes will mostly reflect to increase of air temperature and decrease of precipitations, which can cause the existence of droughts, as extreme manifestations.

Also, analysis of basic climatic data revealed that the dry years were more common in the period after 1981 (Rajic et al., 2010). The global water crisis has drawn worldwide attention to the urgency of achieving a more efficient use of water resources, particularly in agriculture, to increase crop production and achieve world food security (Dabour, 2002).

Current situation in irrigation in our country observed through total number of irrigation systems, or surface area on which they were built, is not satisfactory neither considering range, nor considering technical equipment and the level of use (Potkonjak and Mackic, 2010). Irrigation, being one of ameliorating measures, is certainly most successful way of fighting against drought because it controls soil water balance, which creates favourable conditions for high, stable and economically justified plant production (Kljajic et al., 2013).

Due to the worldwide accepted belief that water is the most important strategic resource XXI century, the management of water resources and management systems for water use and protection is gaining importance (Cecić et al., 2007). Advantages of irrigation are the following: more rational use of natural resources, first of all the use of soil; reduced or eliminated risk from droughts; relation soil-water-plant in accordance at higher rate; higher income per capacity unit; production is economically more efficient; reaching better living standard and higher income of the employees and similar (Sredojevic et al., 2006).

However, it basic use is to apply water to the land aiming to achieve optimal growth and development of cultivated plants when during vegetation there is not sufficient amount of water (Kljajić et al., 2011).

According to the Law on Water of the Republic of Serbia (Official Gazette of Republic of Serbia, no. 30/10), in Serbia a legal status of waters, integral management of waters, management of water facilities and water land, sources and method of funding water activity and other issues significant for managing waters have been arranged. The Republic of Serbia is a downstream country for most of neighbouring countries, while a dominant part of water courses on our territory has the international character. 
Taking it into consideration, Serbia has ratified the Convention on Protection and use of Trans-boundary Water Courses and International Lakes (Official Gazette of Republic of Serbia - International contracts, no. 1/10) and from November 2010 Serbia has become the Convention party.

Significance of the convention on waters for management of water resources on the territory of Serbia can perceive through three fields: water use, protection of waters and protection of waters quality, and generally it has a goal to impel modernization of water resources management system. Traditionally, the efficiency in water use has been looked upon from a technical point of view (Omezzine and Zaibet, 1998).

\section{Methodology and data sources}

In accordance to the state analysis of irrigation, aiming to increase its development, revitalization should be carried out in several phases:

- Capacitate the existing irrigation systems,

- Complete reconstruction of existing irrigation systems, including their enlargement and upgrade (increase of irrigated areas), where it is possible to perform,

- Building new irrigation systems.

Accordingly, the basic goals of the research are:

- Evaluation of factors of agricultural development with the analysis of impact to the planned construction and exploitation of the irrigation system,

- Market aspects of establishing the irrigation system with water of Srem region,

- Evaluation of market efficiency of agricultural production,

- Defining approach for determination of a new sowing structure under irrigation.

In realization of the research task, which refers to the state and tendencies in the regional system of water supply of Srem, the following method of market research will use: Secondary data Analysis or predominantly "Census of Agriculture”, 2012.

Aiming to realize the research task all available sources of informing will be used:

- Census of Agriculture, 2012,

- Survey of Employers, 2012,

- Official Gazette of Republic of Serbia,

- Researches of domestic and foreign authors in the thematic field.

\section{Results with Discussion}

Agriculture is one of the pillars of the Republic of Serbia economic development, and its significance for the national economy besides economic has a social and an ecological component, too. 
A basic characteristic of changes in agrarian structure of Serbia during transition is that they had realized on relation of conversion the state/social ownership into the private (investors were buying great properties with supporting infrastructure, mechanization and facilities), while conveyance of landed properties between private owners was not expressed (private property had not been an object of more significant transactions in which big, external capital, accumulated outside agriculture, would participate).

At this point the review of basic parameters which have a decisive effect or which can affect to the courses of agriculture development (whether positive or negative) in the Republic of Serbia and Srem area will be given.

Factors of positive impact to the courses of agricultural development. The most important factors of positive influence are listed below:

- Favourable natural resources (location, land). The Republic of Serbia has favourable natural conditions for development of diverse agricultural production, since it is located on the most favourable area of northern latitude. Together with climate, land represents the most significant condition for development and assignment of agriculture. In accordance with the SORS (Municipalities and regions in the Republic of Serbia, 2013) agricultural land makes $65.6 \%$ of the Serbian territory. According to data of Census of Agriculture 2012, the Republic of Serbia disposes with 5,346,597 ha of land (agricultural, forest, other land), i.e. with 3,437,423 ha of used agricultural land ( 0.48 ha of used agricultural land per capita). Even $73 \%$ of used agricultural land are plough land and gardens $(2,513,154 \mathrm{ha})$,

- As for water resources, the Republic of Serbia disposes with sufficient amounts of water for satisfaction of its needs, but only if it uses them rationally and protects from accidental or deliberate pollution. Significant wealth represents mineral and thermomineral waters, which diversity of physical and chemical characteristics classify our country into the line of the richest areas on the European continent,

- By numerous agreements on free trade (especially CEFTA agreement, the preferential export to the EU market, Free Trade Agreement with the Russian Federation, Generalized System of Preferences with USA), the Republic of Serbia has created the favourable conditions for foreign trade with commodities in the field of agro-food sector. These agreements provide opportunities to domestic producers and exporters to overcome the problem of small market and increase utilization of capacities on the market several times larger than the domestic one, along with realization of price competitiveness and increase quality of products. Objectively, Serbia has great chances to be the leader in agro-food sector on the territory of SouthEast Europe (export within the CEFTA agreement) and the sector of agriculture has already paved the way toward the European Union market, because almost half of the total export has been directed to the EU market and it has realized a significant surplus in exchange (preferential export of agricultural products on the EU market). The free trade agreement with the Russian Federation provides higher export of Serbian products on the Russian market, and at the same time is one of the greatest 
assets that Serbia has in attracting foreign investments. Preferential export of agrofood products from Serbia to the Russian Federation market (which enables initially the price competition) and higher export of food onto this market can contribute to decrease of trade deficit which Serbia has with Russia and could also help to Serbian producers, especially meat, milk and fruit producers and processors, to achieve the economy of scale through higher export orders, full utilization of capacities and higher foreign exchange incomes. All advantages of free trade with the Russian Federation and other member-countries of the Customs Union (Byelorussia and Kazakhstan) Serbia should take until it accesses the EU, because after that the signed agreements on free trade will no longer be in force,

- Construction and level of technical-technological equipment of food industry has not been mostly a limiting factor of agricultural production increase, but it significantly differs observed by sectors. Certain number of enterprises is at the top of technicaltechnological equipment and they dispose with highly educated personnel, while other enterprises lack behind the modern technological and marketing requests. Since the beginning of privatization process, the most has been invested in industry of oil, beer, milk, confectionery and industry for water processing, while on the other hand, less investments and less technological equipment has been registered in industry for processing of sugar, meat, fruits and vegetables,

Factors of negative impact to the courses of agricultural development:

- Most of arable land is acidified, as the result of uncontrolled use of chemicals, and in Vojvodina it is saline. Accordingly, there are necessary agro-technical measures aiming to improve land structure - calcification, greater use of organic fertilizers, et.

- Water regime, although unfavourable, has been insufficiently used. River courses use insufficiently for irrigation. In accordance to Census of Agriculture 2012, the irrigated area on properties of agricultural husbandries (family agricultural husbandries, legal entities and entrepreneurs) is 99,773 ha (2.9\% of used area). Consequentially, agricultural production depends on precipitations, which are unevenly timely and spatially distributed, depending on atmospheric processes and relief characteristics,

- Ownership structure of agricultural land makes small and fragmentized agricultural holding (used agricultural land per an agricultural husbandry is $5.44 \mathrm{ha}$ ). The census of agriculture in 2012 showed that the average size of totally used land per an agricultural husbandry in Srem amounts 7.82 ha, and even $70.1 \%$ of husbandries have land up to 5 ha. The highest share is of husbandries which use land up to $1 \mathrm{ha}, 34.26 \%$ of them. The biggest average used agricultural land in Srem area is in Inđija (9.18 ha), Stara Pazova (8.27 ha), Sid (8.04 ha), etc.

- There is relatively low utilization of food industry capacities (level of capacities utilization, projected for ex-YU market, ranges from 30-50\%). The highest level of utilization is regarding the capacities for mineral water production, oil factories, mills, capacities for processing of fruits and vegetables, for production of confectionery 
products, breweries, dairies and sugar factories. The lowest level of utilization is regarding the capacities for fodder processing and abattoirs, which causes inefficiency in business and poor competitiveness of this sector,

- Basic limiting factors for more efficient inclusion of food industry onto the international market is as follows: a) insufficient assortment of food products in regard to supply in developed world (insufficiently wide assortment of the existing products, small number of introduction of completely new products and processes, low level of adding value to products through increased role of knowledge, innovations, etc.), b) Vacillating of quality of market products, whether due to lack of standards, or due to disrespect and poor control of the current standards, c) Absence of long-term and firm contractual relations or proprietary connection between food industry and raw materials producers (primary agricultural production),

- Trade liberalization and decrease of customs protection (within the WTO and the Stabilization and Accession Agreement),

- Low competitiveness and innovation of agricultural producers in Serbia. It is necessary to involve small producers in a modern market chain, because they are insufficiently competitive, they trade in informal channels, and their cost of standards introduction is high,

- The current size and structure of agricultural production, its high extensiveness and oscillatory, and low productivity, along with inefficient organization of production-trade flows and inefficient strategies of all types of agro-subjects which do not respect enough the signals of market - are the basic factors which limit achievement of price competitiveness of the domestic producers on the market of agro-food products. Accordingly, it is necessary to reconsider the existing and development of new business and marketing strategies of agricultural producers, based on developmental abilities and power of the producers, but also based on knowing consumers preferences, new technologies, marketing approaches and other modern market postulates of economy,

- Unattractiveness of the primary agriculture and food industry fields for bigger investments, owing to non-established institutions, unfavourable/un motivating business environment, high investment and political risk, high price of capital and many other factors, i.e. the existence of numerous costs,

- Changes in requirements of buyers, their demand or habits cause also changes in functioning of market chains. It is expected these changes to be more expressed in time of the global crisis (Živkov et al., 2009). According to the same source, due to decreased demand on some markets, producers can adjust their production to new requirements; traders must find new markets and adjust to new conditions of sale with much delay in payment, or find new points of sale or new sources of funding.

Natural conditions and production possibilities of Srem area, within which the production realization is planned should use and develop to the utmost, primarily by measures whose 
direct impact will be in function of production and which effects will directly result its size and quality.

By changing the production character, its purposeful decidedness for export, makes the necessary conditions for its more favourable social treatment and its acceptance in sense of a significant factor of economic stabilization and evident and potential source of a significant foreign exchange inflow.

Accordingly there must set up the market mechanisms by which provide technological and production-economic correlation of all participants in production to the final consumption market. Also, irrigation and drainage will be more site-specific and much more closely linked with policies and plans in agriculture and other sectors (Svendsen and Turral, 2007). Analyses have shown that trade reforms combined with institutional reform in the water sector, such as water pricing reforms, or promotion of water market, could prove to be more welfare increasing (Diao and Roe, 2000).

Currently in the Republic of Serbia water for irrigation can be used from almost all sources, but with caution and permanent control (Kljajić, 2014). Crop production is concentrated in the lowlands of the Vojvodina province in the northern part of Serbia, with variable, unstable and unpredictable rainy and dry periods between June and August (Božić et al., 2007).

According to the census of agriculture in 2012, 58,251 ha of agricultural areas were irrigated on the territory of AP Vojvodina, or duplicated in comparison to the year 2010. On the territory of AP Vojvodina, according to data for the year 2010, irrigation was applied for 26,877.50 ha of agricultural areas (Public Water Management Company "Vode Vojvodine", 2010). The most important sources of water for irrigation (Table 1) are ground waters on a husbandry (44.9\%) and surface waters outside a husbandry (40.2\%).

Main sources of water for irrigation in Vojvodina, observed by areas, are:

1. West-Backa area - ground waters on a husbandry $(51.3 \%)$,

2. South-Banat area - surface waters outside a husbandry $(52.8 \%)$,

3. South-Backa area - ground waters on a husbandry $(56.2 \%)$,

4. North-Banat area - surface waters outside a husbandry $(52.3 \%)$,

5. North-Backa area - ground waters on a husbandry $(70.2 \%)$,

6. Mid-Banat area - surface waters outside a husbandry $(63.7 \%)$,

7. Srem area - ground waters on a husbandry (49.0\%). 
Table 1. Methods of irrigation and main sources of water for irrigation in Vojvodina

\begin{tabular}{|c|c|c|c|c|c|c|c|c|}
\hline \multirow[b]{2}{*}{ 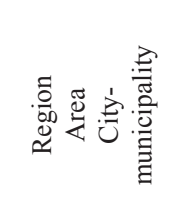 } & \multicolumn{3}{|c|}{ Methods of irrigation } & \multicolumn{5}{|c|}{ Main sources of water for irrigation } \\
\hline & 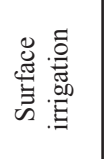 & 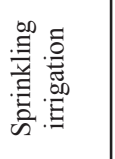 & 을. & 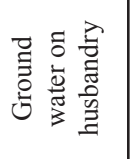 & 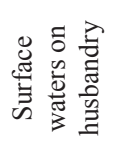 & 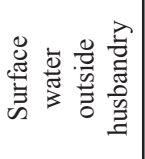 & 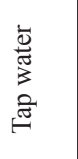 & 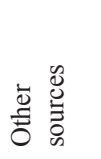 \\
\hline $\begin{array}{l}\text { Vojvodina } \\
\text { region }\end{array}$ & 38.7 & 25.0 & 36.2 & 44.9 & 5.2 & 40.2 & 5.1 & 4.6 \\
\hline $\begin{array}{l}\text { West-Backa } \\
\text { area }\end{array}$ & 34.4 & 20.6 & 44.9 & 51.3 & 5.5 & 30.9 & 4.2 & 8.1 \\
\hline $\begin{array}{l}\text { South-Banat } \\
\text { area }\end{array}$ & 43.9 & 17.8 & 38.3 & 30.0 & 7.0 & 52.8 & 7.9 & 2.4 \\
\hline $\begin{array}{l}\text { South-Backa } \\
\text { area }\end{array}$ & 37.7 & 33.1 & 29.2 & 56.2 & 5.7 & 30.9 & 3.5 & 3.6 \\
\hline $\begin{array}{l}\text { North-Banat } \\
\text { area }\end{array}$ & 48.7 & 31.8 & 19.5 & 37.5 & 2.8 & 52.3 & 5.2 & 2.2 \\
\hline $\begin{array}{l}\text { North-Backa } \\
\text { area }\end{array}$ & 30.4 & 28.7 & 41.0 & 70.2 & 2.9 & 17.7 & 6.3 & 2.9 \\
\hline Mid-Banat area & 36.8 & 21.8 & 41.4 & 22.8 & 3.3 & 63.7 & 4.4 & 5.8 \\
\hline Srem area & 37.4 & 18.3 & 44.3 & 49.0 & 5.9 & 33.8 & 5.3 & 5.9 \\
\hline
\end{tabular}

Source: Census of Agriculture - 2012.

In the area of Srem are irrigated 3,655 ha of land in total. The irrigated land of Srem area according to the categories of use: plough land and gardens 2,484 ha, orchards 1,152 ha, vineyards 11 ha, meadows and pastures 3 ha and other perennial plantations 5 ha (Table 2).

Table 2. Irrigated land according to categories of use in agricultural 2011/2012

\begin{tabular}{|c|c|c|c|c|c|c|c|c|c|c|c|c|}
\hline \multirow{2}{*}{$\begin{array}{c}\text { Region - } \\
\text { City } \\
\text {-municipality }\end{array}$} & \multicolumn{2}{|c|}{ Irrigated land } & \multicolumn{2}{|c|}{$\begin{array}{l}\text { Plough land and } \\
\text { gardens }\end{array}$} & \multicolumn{2}{|c|}{ Orchards } & \multicolumn{2}{|c|}{ Vineyards } & \multicolumn{2}{|c|}{$\begin{array}{c}\text { Meadows } \\
\text { and pastures }\end{array}$} & \multicolumn{2}{|c|}{$\begin{array}{c}\text { Other } \\
\text { perennial } \\
\text { plantations }\end{array}$} \\
\hline & PG & ha & $\mathrm{PG}$ & ha & PG & ha & PG & ha & $P G$ & ha & PG & ha \\
\hline Srem area & 1,378 & 3,655 & 1,147 & 2,484 & 248 & 1,152 & 19 & 11 & 2 & 3 & 5 & 5 \\
\hline Indjija & 75 & 138 & 47 & 76 & 28 & 55 & 6 & 5 & - & - & 2 & 3 \\
\hline Irig & 33 & 352 & 14 & 33 & 17 & 316 & 3 & 3 & - & - & - & - \\
\hline Pecinci & 174 & 378 & 152 & 242 & 24 & 135 & 1 & 1 & - & - & - & - \\
\hline Ruma & 508 & 1,108 & 446 & 968 & 73 & 136 & 1 & 0 & 1 & 2 & 1 & 1 \\
\hline $\begin{array}{l}\text { Sremska } \\
\text { Mitrovica }\end{array}$ & 438 & 941 & 397 & 892 & 46 & 48 & 5 & 2 & 1 & 0 & - & - \\
\hline Stara Pazova & 79 & 231 & 63 & 190 & 17 & 40 & 2 & 1 & - & - & - & - \\
\hline Šid & 71 & 507 & 28 & 83 & 43 & 422 & 1 & 0 & - & - & 2 & 2 \\
\hline
\end{tabular}

Source: Census of Agriculture - 2012.

Of totally irrigated land in Srem the largest irrigated area is in Ruma (1,108 ha), then Sremska Mitrovica (941 ha) Sid (507 ha) etc. The smallest irrigated area is registered in Inđija (138 ha). If the percentage of the total irrigated areas under crops (plough land and gardens) analyses there can see that the best coverage is regarding vegetables, melons and strawberries (in open field), 49.2\%. Sugar beet follows with 2.9\%; other crops on plough land and gardens $(1.2 \%)$; cereals and maize for silage $(0.4 \%)$, and finally sunflowers with 
only $0.1 \%$, which irrigates of the total area under this crop (Census of Agriculture, 2012). The most common way for irrigation in Srem is drop irrigation (44.3\%). Also is significant surface irrigation (37.4\%), while sprinkling irrigation is rarest $(18.3 \%)$. The main sources of water for irrigation in Srem are: ground waters on a husbandry $-49.0 \%$; surface water on a husbandry $-5.9 \%$; surface waters outside a husbandry $-33.8 \%$; tap water $-5.3 \%$ and other sources $-5.9 \%$ (Table 3 ).

Table 3. Methods of irrigation and main sources of water for irrigation in Srem

\begin{tabular}{|c|c|c|c|c|c|c|c|c|}
\hline \multirow[b]{2}{*}{ 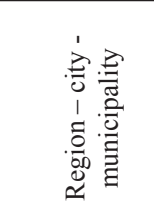 } & \multicolumn{3}{|c|}{ Methods of irrigation } & \multicolumn{5}{|c|}{ Main sources of water for irrigation } \\
\hline & 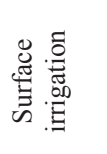 & 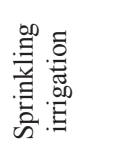 & 员. & 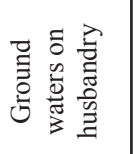 & 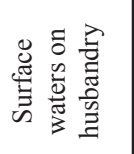 & 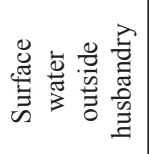 & 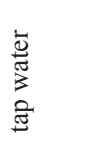 & 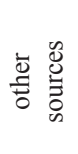 \\
\hline Srem area & 37.4 & 18.3 & 44.3 & 49.0 & 5.9 & 33.8 & 5.3 & 5.9 \\
\hline Indjija & 39.2 & 16.9 & 43.9 & 38.0 & 9.4 & 43.0 & 7.0 & 2.6 \\
\hline Irig & 38.3 & 17.0 & 44.7 & 34.0 & 6.9 & 26.2 & 23.2 & 9.7 \\
\hline Pecinci & 19.6 & 11.1 & 69.3 & 65.2 & 6.8 & 22.2 & 1.1 & 4.7 \\
\hline Ruma & 25.8 & 23.2 & 51.1 & 43.1 & 8.0 & 39.5 & 3.3 & 6.1 \\
\hline $\begin{array}{l}\text { Sremska } \\
\text { Mitrovica }\end{array}$ & 60.0 & 17.6 & 22.5 & 57.9 & 3.3 & 31.2 & 2.8 & 4.8 \\
\hline Stara Pazova & 44.7 & 19.1 & 36.2 & 37.1 & 4.7 & 36.2 & 8.8 & 13.2 \\
\hline Šid & 31.8 & 10.9 & 27.3 & 40.3 & 9.1 & 40.7 & 7.2 & 2.7 \\
\hline
\end{tabular}

Source: Census of Agriculture - 2012.

In domestic agro ecological conditions, it is possible to realize various production and economic effects of irrigated crops (Potkonjak and Mackic, 2010). Taking into consideration the current state of irrigation system in Vojvodina and Srem area and a need for provision of sufficient amounts of water to crops during the vegetation period, it is necessary to revitalize the irrigation system, in order to raise it to the European level and improve agricultural production by its apply.

Irrigation has a large impact on yield production and intensification of agricultural production (Babović et al., 2009). Namely, by irrigation increases the agricultural production efficiency, there makes impact to sowing structure change, and the market surpluses on the international market can be sold, by using the existing international agreements, signed by the Republic of Serbia. However, besides a great potential in the sector of agricultural production, as the result of favourable climatic conditions, natural land characteristics and available water resources, signed agreements on free trade - the potentials in agro-food sector have not been sufficiently used.

The largest area of agricultural land in Serbia is used for production of cereals and this production occupies around $60 \%$ of total plough land and gardens. Maize is the most common crop with over 1.2 million of seeded acres, while wheat is right behind with around half million acres. Due to large sown areas, among sectors with the highest value of primary production are cereals, which additionally increase with further processing. Cereals production satisfies the needs of the domestic processing industry and certain 
amounts export. Thanks to favourable trends regarding prices of cereals on the international market, which were reaching their maximum during 2008 and 2011 there was noticeable the trend of cereals production increase, in past several years, thanks to maize, while wheat and barley were stagnated and the production decreased in Vojvodina (Živkov et al., 2012). In Srem area under cereals is 147.058 ha (Table 4).

Table 4. Areas under grains in Srem area

\begin{tabular}{|c|c|c|c|c|c|c|c|c|}
\hline \multirow[b]{2}{*}{$\begin{array}{l}\text { Region - city } \\
\text {-municipality }\end{array}$} & \multirow{2}{*}{$\begin{array}{l}\text { Number of } \\
\text { agricultural } \\
\text { husbandries }\end{array}$} & \multicolumn{7}{|c|}{ Grains, ha } \\
\hline & & Total & $\begin{array}{c}\text { Wheat and } \\
\text { spelt }\end{array}$ & Rye & Barley & Oat & Maize & $\begin{array}{l}\text { Other cereals } \\
\text { for grains }\end{array}$ \\
\hline Srem area & 21,233 & 147,058 & 54,928 & 71 & 3,775 & 154 & 86,810 & 1,320 \\
\hline Indjija & 2,332 & 19,011 & 6,786 & 2 & 161 & 44 & 11,958 & 61 \\
\hline Irig & 1,176 & 7,039 & 2,971 & - & 83 & 21 & 3,864 & 100 \\
\hline Pećinci & 2,497 & 18,036 & 8,420 & 11 & 1,063 & 15 & 8,235 & 292 \\
\hline Ruma & 3,856 & 28,540 & 11,063 & 4 & 578 & 9 & 16,651 & 236 \\
\hline Sremska Mitrovica & 5,812 & 35,755 & 13,284 & 14 & 675 & 35 & 21,432 & 315 \\
\hline Stara Pazova & 2,411 & 20,335 & 6,076 & 6 & 378 & 23 & 13,166 & 186 \\
\hline Šid & 3,149 & 18,342 & 6,329 & 35 & 338 & 7 & 11,504 & 129 \\
\hline
\end{tabular}

Source: Census of Agriculture - 2012.

Table 5 shows competitiveness of individual products, expressed through the average ratings of two parameters: production and export. The average ratings calculated according to evaluation of: a) significance of size and increase of production, and b) value and increase of export in regard to the competitive countries (Živkov et al., 2012). In this way can see clearly which products have export potential, but they are insufficiently present in production in Vojvodina, and which production should reorientate to the one with greater potential.

New sowing structure under irrigation should respect ranking the competitiveness of individual products according to evaluations of significance of production and export (Table 5). In this context, it is important to point out the following (Živkov et al., 2012):

- Maize and industrial plants have good competitive position, along with carrot, because shares of production and value of export of these products are very significant, i.e. the average annual growth rates of production and export are significantly higher in regard to competitors,

- In principle, fruits have a good position concerning production and export,

- Situation regarding vegetables varies from product to product,

- Concerning cereals, the worse position has barley, owing to the value and the growth rate of this product's export, while vegetable worst position has potatoes. 
Table 5. Calculation and ranking of single products competitiveness according to evaluation of significance of production and export, region of AP Vojvodina

\begin{tabular}{|l|c|c|}
\hline \multicolumn{1}{|c|}{ Product } & $\begin{array}{c}\text { Average rating of } \\
\text { production and export }\end{array}$ & $\begin{array}{c}\text { Evaluation of significance for } \\
\text { rural development }\end{array}$ \\
\hline Wheat & 3.13 & 5.00 \\
\hline Barley & 1.93 & 2.00 \\
\hline Maize & 3.87 & 5.00 \\
\hline Soy & 3.77 & 3.00 \\
\hline Potato & 1.88 & 4.00 \\
\hline Apple & 2.88 & 4.00 \\
\hline Plum & 3.15 & 3.00 \\
\hline Pear & 3.03 & 1.00 \\
\hline Sour cherry & 3.85 & 1.00 \\
\hline Peach & 2.78 & 1.00 \\
\hline Pepper & 2.15 & 4.00 \\
\hline Onion & 3.02 & 4.00 \\
\hline Tomato & 2.55 & 4.00 \\
\hline Cucumber & 2.42 & 3.00 \\
\hline Carrot & 4.25 & 3.00 \\
\hline Milk & 2.12 & 5.00 \\
\hline Beef & 2.30 & 4.00 \\
\hline Pork & 2.68 & 5.00 \\
\hline Mutton & 2.73 & 2.00 \\
\hline Sugar beet and sugar & 4.05 & 2.00 \\
\hline Sunflower and oil & 3.10 & 3.00 \\
\hline
\end{tabular}

Source: Živkov et al., 2012. Note: The obtained values were evaluated from 1 to 5, in a way that a product with the highest share or the highest growth rate of production in regard to the competitive got 5 , and the one with the lowest got 1 . In accordance to the production and export evaluation was calculated the average rating of products competitiveness, as a unique value which determines position and potential of the specific product in regard to others.

Expected yields in irrigation systems are higher than production in terms without irrigation for around $30 \%$, but also up to $100 \%$ in years with unfavourable distribution of rainfall, i.e. longer dry periods. Consequently, safety of production can be largely guaranteed (if all the rest conditions of good agricultural practice are satisfied) in production terms of irrigation. On average, the efficiency and influence of irrigation on increase of crop yields in practice and experiments amount from $30 \%$ to $50 \%$ regarding potato, from $50 \%$ to $100 \%$ higher yield of onion, from $20 \%$ to $50 \%$ higher yield of seed maize and sugar beet, the yield of pepper is higher from $40 \%$ to $60 \%$ and apple from $30 \%$ to $40 \%$ (Cvijanović et al., 2012). Effects of irrigation on the value of crop production and reimbursement margin of variable costs, as in cereals production, as well as in production of industrial plants, are expressed through increase of incomes and the reimbursement margin. 


\section{Conclusion}

Taking into consideration the current state of irrigation system in the Republic of Serbia and Srem region and a need for providing sufficient amount of water to crops during the vegetation period, it is necessary to make revitalization of the irrigation system, in order to raise it to the European level and improve the agricultural production by its apply. Increasing lack of water resources, their irrational consumption and insufficient protection, along with unfavourable consequences of climatic changes, represent limiting factors of economic development in many regions of the world, among which is also the region of South-East Europe. These are the problems the Republic of Serbia faces with. Generally, in the Republic of Serbia, which has been characterized by the changeable climatic conditions, where precipitations by their amounts and disposition, vary from year to year, irrigation has been a significant factor of increase and stabilization of agricultural production. Analyses show that droughts in the Republic of Serbia appear every third to fifth year in average, and culmination was in the year 2000 when long-term drought had the character of natural disaster and it had significantly diminished agricultural production, which had left very serious trace to the entire national economy, too. According to the carried out research can draw the following conclusions in the context of irrigation:

- Most of crops and forage crops are not payable for irrigation and for that reason should be careful while making decisions which of the mentioned crops and for what purpose should be produced. Success of irrigation requires knowing specificities of specific plant species and their genotypes. In the sowing structure to a greater extent some of industrial plants can be represented in irrigation, and which reacts well on irrigation. Some of potentially interesting crops and forage crops in terms of irrigation can be: a) seed production of maize, b) mercantile maize and soy production, c) seed production (sugar beet, soy), d) mercantile production (sugar beet, sunflower and tobacco), e) plants as second crop or for double-cropping sowing, by which accomplish "second sowing" in a production year. For example, maize in irrigation conditions tolerates postponing of sowing period, which enables production of winter crops of inter-seasonal sowing for green fodder. Furthermore, prolongation of sowing enables performing other spring works.

- Vegetable production cannot imagine without provision of sufficient amounts of water for irrigation. Fruit and vegetable production have the largest irrigated areas. All vegetable plants require a higher level of soil moisture in comparison with crops, owing to less developed root system in regard to above-ground system which uses large amounts of water. Nevertheless vegetable plants contain large amount of water in tissue. All of these things complicate irrigation a lot and it requires daily tracking of relative soil moisture, because a deficit leads to decrease of yields, while increased content leads to occurrence of disease and violation of water-air regime vegetable plants are very sensitive to.

- Fruit growing and vine growing. Irrigation of orchards and vineyards contributes to high yields and stable production of high quality. Most of fruit trees react well to irrigation by increasing yields and quality of fruits, as well grapevine. Mostly used ways of irrigation in fruit and wine growing are "drop" irrigation systems. 


\section{Literature}

1. Babović, J., Milić, S., Radojević, V. (2009): Ekonomski efekti navodnjavanja u biljnoj proizvodnji, Ekonomika poljoprivrede, vol. 56, no. 1, pp. 41-53.

2. Božić, M., Nikolić, G., Stević, D., Životić, L., Dragović, S. (2007): Ublažavanje suše primenom navodnjavanja u proizvodnji kukuruza, Vodoprivreda, vol. 39, no. 5-6, pp. 357-365.

3. Cecić, N., Cvijanović, D., Vuković, P. (2007): Hidrografski resurs, nedovoljno iskorišćena šansa sela Glogonj, Ekonomika, vol. 53, br. 5-6, pp. 68-77.

4. Cvijanović, D., Subić, J., Kljajić, N., Filipović, V. (2012): Stanje i mogućnosti razvoja navodnjavanja u Republici Srbiji, nacrt, Nepublikovan material, Institut za ekonomiku poljoprivrede, Beograd.

5. Dabour, N. M. (2002): The role of irrigation in food production and agricultural development in the Near East Region, Journal of Economic Cooperation, vol. 23, no. 3 pp. 31-70.

6. Diao, X., Roe, T. (2000): The Win-Win Effect of Joint Water Market and Trade Reform on Interest Groups in Irrigated Agriculture in Morocco, In: Dinar, A. (ed.): The Political Economy of Water Pricing Reforms, Oxford University Press, New York, USA.

7. International Labour Organization (2010): Uslovi i opterećenja u privredi Srbije, brochure Serbian Association of Employers, Austrian Development Agency (ADA), part of Project „Konsolidacija pravnih i institucionalnih osnova socijalnog dijaloga u zemljama zapadnog Balkana i Moldaviji“, International Labour Organization, office for Central and East Europe, Belgrade, Serbia.

8. Kljajić, N. (2014): Efikasnost investicija u proizvodnji maline, monografija, Institut za ekonomiku poljoprivrede, Beograd.

9. Kljajić, N., Vuković, P., Arsić, S. (2011): Irrigation in Serbia - development conditions and perspectives, Scientific papers series: Management, Economic engineering in Agriculture and Rural Development, vol. 11, no. 1, pp. 100-106.

10.Kljajić, N., Vuković, P., Arsić, S. (2013): Current situation in irrigation in the Republic of Serbia, In: Andrei, J., Turek, A., Subic, J., Dusmanescu, D. (Ed.) Sustainable Technologies, Policies, and Constraints in the Green Economy, IGI Global, Hershey, PA, USA, pp. 123-139.

11. Konvencija o zaštiti i korišćenju prekograničnih vodotokova i međunarodnih jezera, Službeni glasnik Republike Srbije, Međunarodni ugovori, br. 1/10.

12.Milly, P. C. D., Betancourt, J., Falkenmark, M., Hirsch, R. M., Kundzewicz, Z. W., Lettenmaier, D. P., Stouffer, R. J. (2008): Stationarity is dead: Whither water management?, Science, vol. 319, no. 5863, pp. 573-574.

13. National Employment Service of Serbia (2012): Analiza tržišta rada i prognoziranje potreba na tržištu rada u Republici Srbiji, National Employment Service of Serbia and USAID, Belgrade, Serbia.

14.Omezzine, A., Zaibet, L. (1998): Management of Modern Irrigation Systems in 
Oman: Allocative vs. Irrigation Efficiency, Agriculture Water Management, vol. 37, pp. 99-107.

15.Potkonjak, S., Mačkić, K. (2010): Proizvodno-ekonomski efekti navodnjavanja sa posebnim osvrtom na male površine, Savremena poljoprivredna tehnika, vol. 36, no. 3, pp. 256-266.

16. Public Water Management Company "Vode Vojvodine" (2010), internal documentation, Novi Sad.

17.Rajić, M., Belić, A., Josimov Dunđerski, J. (2010): Meteorološke i hidrološke podloge potrebne za navodnjavanje u Vojvodini, Savremena poljoprivreda, vol. 59, br. 3-4, str. 312-318.

18. Sredojević, Z., Gajić, B., Živković, D. (2006): Ekonomski parametri optimalne strukture proizvodnje u uslovima navodnjavanja, Zbornik radova sa skupa sa međunarodnim učešćem: II - Perspektive agrobiznisa Srbije i Evropske integracije, Ekonomika poljoprivrede, Vol. LIII, br. 3, pp. 799-809.

19. Statistical Office of the Republic of Serbia, SORS (2013): Census of Agriculture 2012, book 1, SORS, Belgrade, Serbia.

20. Statistical Office of the Republic of Serbia, SORS (2013): Opštine i regioni u Republici Srbiji 2012, SORS, Belgrade, Serbia.

21. Svendsen, M., Turral, H. (2007): Reinventing irrigation, In: Molden, D. (Ed.): Water for food, water for life: A Comprehensive Assessment of Water Management in Agriculture, London, UK: Earthscan, Colombo, Sri Lanka: IWMI, pp. 353-394.

22.Zakon o vodama Republike Srbije, Službeni glasnik Republike Srbije, br. 30/10.

23.Živkov, G., Obućina, B., Teofilović, N., Bernardoni, P., Dulić Marković, I., Bardić, D., Božić, M. (2012): Analiza trendova u proizvodnji i trgovini poljoprivrednih proizvoda iz Vojvodine u odnosu na proizvodnju i trgovinu u Srbiji, regionu, EU i svetu, Studija za Program: Fond za promociju izvoza poljoprivrednih proizvoda, APF red. Br. JNMV 19/2012, Seedev, Beograd.

24.Živkov, G., Vonnegut, A., Obućina, B., Popadić, N. (2009): Uticaj svetske ekonomske krize na poljoprivredu Srbije, USAID, Beograd. 


\title{
ULOGA NAVODNJAVANJA U RAZVOJU POLJOPRIVREDE SREMSKOG OKRUGA
}

\author{
Branko Mihailovićc, Drago Cvijanović ${ }^{7}$, Ivan Milojevićs ${ }^{8}$, Milorad Filipovićc
}

\begin{abstract}
Sažetak
Primenom navodnjavanja se dobijaju visoki proizvodni rezultati, a ekonomičnost ulaganja u irigacione sisteme ukazuje da ovoj meri u poljoprivrednoj proizvodnji treba dati prioritet. Navodnjavanjem se može stabilizovati, odnosno uvećati proizvodnja hrane i podstaći razvoj stočarstva, prerađivačkih i drugih grana privrede u regionu Vojvodine i oblasti Srema. Shodno tome, osnovni ciljevi istraživanja su: 1) ocena faktora poljoprivrednog razvoja sa analizom uticaja na planiranu izgradnju i eksploataciju sistema za navodnjavanje; 2) tržišni aspekti uspostavljanja sistema snabdevanja vodom regiona Srem; 3) ocena tržišne efikasnosti poljoprivredne proizvodnje $i$ 4) definisanje pristupa za određivanje nove setvene strukture pod navodnjavanjem.

Istraživanje je pokazalo da se navodnjavanjem povećava efikasnost poljoprivredne proizvodnje, utiče se na promenu setvene strukture, a tržišni viškovi se mogu plasirati na međunarodno tržište iskorišćavanjem postojećih međunarodnih sporazuma koje je potpisala Republika Srbija. Međutim, i pored velikog potencijala u sektoru poljoprivredne proizvodnje koji je rezultat povoljnih klimatskih uslova, prirodnih karakteristika zemljišta i raspoloživih vodnih resursa, potpisanih sporazuma o slobodnoj trgovini - potencijali u poljoprivredno prehrambenom sektoru nisu iskorišćeni.
\end{abstract}

Ključne reči: navodnjavanje, poljoprivredni razvoj, konkurentnost, efikasnost.

6 Dr Branko Mihailović, naučni saradnik, Institut za ekonomiku poljoprivrede, Volgina 15, 11060 Beograd, Srbija, Telefon: +381 116972 858, E-mail: brankomih@neobee.net

7 Prof. dr Drago Cvijanović, naučni savetnik, Institut za ekonomiku poljoprivrede, Volgina 15, 11060 Beograd, Srbija, Telefon: +381 116972 858, E-mail: drago c@iep.bg.ac.rs

8 Prof. dr Ivan Milojević, Vojna akademija, Univerzitet odbrane, Pavla Jurišića Šturma 33, 11000 Beograd, Srbija, Telefon: +381 113603 247, E-mail: drimilojevic@gmail.com

9 Prof. dr Milorad Filipović, Univerzitet u Beogradu, Ekonomski fakultet, Kamenička 6, 11000 Beograd, Srbija, Telefon: +381 6413809 46, E-mail: miloradf@ekefof.bg.ac.rs 